\title{
KERALA STATE COOPERATIVE BANK AS AN APEX BANK - A STUDY
}

\section{LEKSHMI. V}

\author{
Research Scholar, Department of History, S. T. Hindu College, Nagarcoil, Tamil Nadu, India
}

The institution of cooperation has a long history to speak. It is an instinct in man to work together, line together and grow together. This 'togetherness' built family, society, district and nation. This togetherness is the mother of all civilizations. Also, this togetherness is the backbone of all the cooperative endeavor. There are many cooperative institutions in all over and this led to the formation of apex institutions like, the State Co-operative Bank, The State Agricultural and Rural Development Bank, the Urban Bank. The Co-operative movement in Kerala like its counterparts is essentially a child of distress. It focused its attention mainly on the problems of farmers. Because they were severely under the clutches of money lenders and the co-operative movement played a vital role in releasing these people from money lenders who extracted heavy interest and treated them like slaves.

KEYWORDS: Kerala State Cooperative Bank, KSCB, Co-Operative \& Apex Bank
\end{abstract}

Received: Feb 12, 2019; Accepted: Mar 02 2019; Published: Mar 05, 2019; Paper Id.: IJEEFUSAPR20198

\section{INTRODUCTION}

The cooperative movement started in Kerala to redeem the peasants from the clutches of moneylenders. The Kerala State Cooperative Bank is the product of these innovative thought ${ }^{1}$. It acts as an apex cooperative bank and maintains a federal character. By apex bank means, KSCB provides all the guidelines and support to District Cooperative Banks and Primary Agricultural Cooperative Societies. In early days Kerala State Cooperative Bank started branches in all over Kerala. But later when there arises a need of District Cooperative Bank KSCB converted all its branches into DCB's and makes them its members. Now the members of KSCB are District Cooperative Banks and the Government itself..$^{2}$ In Kerala there are 14 District Co-operative Banks and all of them have membership in KSCB. When Sri.Thachadi Prabakaran became the president of KSCB, 45 cents of land near Palayam was granted by the Government to construct the Head Office. The foundation stone was laid by the then President of India Sri. Sanjeeva Reddi in 1881 and the construction started in 1982. It was completed in 1987, the building was named as 'COBANK Tower'. The inaugural ceremony was conducted by the State Governor, Sri.P.Ramachandran. The COBANK tower is a fourteen storied building. Now the bank gave consideration for starting new branches in all the districts. Now it has three regional offices and twenty branches all over Kerala.

\section{DISTRICT COOPERATIVE BANKS IN KERALA}

Kozhikode District Co-operative Bank was the first one and it was registered in $1917 .^{4}$ In the very same year the bank got much acceptability in the mind of people and there were 75 co-operative societies and 125 individuals became members. The bank collected Rs.13330 as share capital. At present bank have branches in Kozhikode, Koyilandi, and Vadakara. The Cochin Central Co-operative Bank was affiliated as a district Co-operative bank. This bank became the chief source of financial aid to all the primary societies of Thrissur and Cochin districts. When District Co-operative Banks were reorganized on the basis of revenue districts in 1961 the 
service area of the Thrissur District Co-operative Bank was limited to the Thrissur revenue district and the bank was renamed as Thrissur District Co-operative Bank. Till 1978, the bank extended finance only through Primary Co-operatives and in 1978, it started direct finance to individuals also.Now the bank has 58 branches. ${ }^{5}$ A branch of State Co-operative Bank in a rented building near the telegraph office on the M.G.Road, Kottayam was inaugurated by Sri. B. Ramakrishna Rao on 30th November 1956. When there arises an idea about a district co-operative bank for Kottayam, this branch of Kerala State Co-operative Bank was converted as Kottayam District Co-operative Bank and started functioning in 1-9-1958. It has the business of Rs.1711 crores as deposit and Rs.1162-85 crores as loan through its 58 branches. Kollam District Co-operative Bank started functioning from 1-9-1958. It is the Kollam District Co-operative Bank, that started for the first time 'Taluk Developmental committees. ${ }^{, 6}$ The chief work of this committee is to ensure the work and development of Primary societies of all the taluks in Kollam district. Now this DCB has 57 branches and 988 member societies. Along with Kerala State Co-operative Bank, Thiruvananthapuram has its own District Co-operative Bank. It was registered on 1-8-1958 and started working on 12-8-1958. It is the largest District Co-operative Bank in Kerala. This DCB has 83 branches and one mobile branch. Alappuzha District Co-operative Bank started by converting a branch of Kerala State Co-operative Bank which worked in Alappuzha. It was registered as DCB on 31-7-1959 and started functioning from 1-9-1959 with its headquarters at Alappuzha.This District Co-operative Bank is a great step towards financing needy cultivators at low rate of interest and it became a great success. Now this bank has 819 members and 56 branches. After the formation of Ernakulam as a revenue district in 1960 the branch of Kerala State Co-operative Bank was converted and registered as Ernakulam District Co-operative Bank. Now Ernakulam DCB has 54 branches and 644 members.

As instructed by the Rural Credit survey committee and with the special interest taken by the Registrar of co-operative societies, the Kannoor District Co-operative Bank was formed and registered on 22-05-1963. After the formation of Palakkad from by reorganizationthe old Malabar districtlabar district, Palakkad District Co-operative Bank was formed. This DCB has 43 branches all over the district. The DCB for Malappuram was formed on 1-7-1970. In the beginning, it had only 163 members. Because of public demand Malappuram DCB started several branches. It also started three evening branches, among which one was a women's branch. Now the Bank has 46 branches. Idukki DCB started functioning from 1-7-1973. It had branches at Adimali, Moonar and Kattapana acquired from Kottayam District Cooperative Bank. In the year 1996-97, it was selected as the best district co-operative bank and it also won medal from NABARD. It also won awardscollectingthe maximum amountmaximum amount as deposits in the year 1976. This DCB has 46 branches. Wayanad DCB was started its working on 1-10-1982. The bank gave more importance to finance low income group forhousestructing house in association with Grama Panchayats.And also farmer friendly activities are undertaken through 26 farmers clubs. Pathanamthitta DCB was another important bank, which started to function on 1-7-1985. For empowering women customers, the bank has a separate women's development wing. The Kasercode district was formed on 24 May 1984 as the fourteenth district of Kerala state. But a co-operative bank for Kasarcode district was established only after two years. The Kasarcode DCB started functioning from 1st October 1986. The Kasarcode DCB created a Primary Agricultural Co-operative Development Cell with the support of NABARD aiming at overall development of PACS which are affiliated to the Bank.

\section{PRIMARY AGRICULTURAL COOPERATIVE SOCIETIES}

Primary Agricultural Cooperative societies are banks in rural areas and play a prominenthe rural credit systemdit system. They are the banks that work under the District Cooperative Bank. These PACS occupy the third and primary 
position in the three tier structure followed by the State Cooperative Bank and this federal structure helps and gave strength to these societies which is at the village or base level. ${ }^{7}$ The Primary Agricultural Cooperative societies get assistance from NABARD, State Government, District Cooperative Banks and also as a form of deposits from their members and others. But one of the important facts which we have to notice that, these PACS have no direct financial dealings with NABARD and State Government. It is the apex bank, that is, the Kerala State Co-operative Bank through its District Cooperative Banks makes them available all the beneficiaries granted by NABARD and Government itself. If the Primary society has no fund at its disposal, it applies to the District Cooperative Bank and if they need fund they apply to the State Bank. It gives a clear picture about the importance and working of three tier cooperative structure existing in Kerala. In case they are incapable of meeting the loan demands, they fix the limit of the loans for agricultural as well as non-agricultural purposes from the District Co-operative Banks before time limit. District Cooperative Banks with the permission of State Cooperative Bank and the Cooperative Registrar fix a loan limit to these societies. These primary societies often distribute agricultural implements, seeds and fertilizers among its members. They often collect and store agricultural products such as paddy, coconut, sugar and oil by offering the producers affordable price. There have been several Primary Cooperative societies which have made a record in managing cooperative mills, cooperative factories like that. Now there are more than 1600 societies working in fourteen districts. ${ }^{8}$ All the policies and programs introduced by the Kerala State Co-operative Bank are implemented among the common people through these Primary Agricultural Co-operative Societies ${ }^{9}$

\section{CONCLUSIONS}

The origin of the co-operative banks in Kerala was mainly for common people. In the three tier co-operative structure, the primary agricultural co-operative societies are meant to mingle freely with common people. As earlier said, there are many primary agricultural co-operative societies which not only satisfy the financial requirements of the common people, but also distribute seeds, fertilizers and agricultural implements.And Kerala State Cooperative Bank through its District Cooperative Bank render all the assistance to these Primary Agricultural Cooperative Societies. This is the unique quality of Kerala State Cooperative Bank.

\section{REFERENCES}

1. Gangadharan, R., Vaipedara Sangangal (Mal.), Trivandrum, 2004, p.24

2. Annual Report, Kerala State Cooperative Bank, Trivandrum, 2002, p.2

3. Annual Report, Kerala State Cooperative Bank, Trivandrum, 1992, p.6

4. Annual Report, Kerala State Cooperative Bank, Trivandrum, 1918, p.8

5. Tankappan, E.O., Sahakarana Niyamangalum Ithara Niyamangalum(Mal), Ernakulam, 1996, p.140

6. Thushar, M.K., Asset Management in Primary Societies, New Deihi, 2000, pp.251-253

7. Padmanabhamenon, Sahakarana Sangangalude Ghatanayum Pravarthanavum(Mal.), Trivandrum, 1984, p.146

8. Pillai, B.P., The Kerala State Cooperative Bank-A Brief History, Trivandrum, 2004, p.138

9. Prabhakaran Nair, V., Sahakarana Babking Sthapanangal(Mal.), Trivandrum, 2015, p.84

10. Prabu, G. G., \& Chandrasekaran, G. (2015). A Comparative Study on Financial Performance of State Bank of India and ICICI Bank. International Journal of Research in Business Management, 3(4), 19-26. 
